\title{
Clinical and Prognostic Significance of Promoter Polymorphism (-31GC) of Anti Apoptotic Gene Survivin (BIRC5) in North India Patients with Non Small Cell Lung Cancer
}

\author{
Jamsheed Javid ${ }^{1}$, AB Rashid Mir ${ }^{2}$, Imtiyaz Ahamad ${ }^{1}$, Shazia Farooq ${ }^{1}$, Prasant Yadav ${ }^{1}$, Maryam Zubari ${ }^{1}$, M Masroor ${ }^{1}$, PC Ray $^{3}$, PK Julka ${ }^{4}$ \\ Anant Mohan ${ }^{5}$, Maqbool Lone ${ }^{6}$, MA Banday $^{7}$ and Alpana Saxena ${ }^{8 *}$ \\ ${ }^{1}$ Research Scholar, Molecular Oncology Lab, Department of Biochemistry, Maulana Azad Medical College and Associated hospitals, New Delhi, India \\ ${ }^{2}$ Research Scientist, Molecular Oncology Lab, Department of Biochemistry, Maulana Azad Medical College and Associated hospitals, New Delhi, India \\ ${ }^{3}$ Director-Professor, Molecular Oncology Lab, Department of Biochemistry, Maulana Azad Medical College and Associated hospitals, New Delhi, India. \\ ${ }^{4}$ Professor and Head, Department of Radiotherapy, All India Institute of Medical Sciences, New Delhi, India \\ ${ }^{5}$ Associate professor Department of Medicine, All India Institute of Medical Sciences, New Delhi, India \\ ${ }^{6} \mathrm{Head}$, Department of Radiation Oncology, SKIMS, Srinagar, India \\ ${ }^{7}$ Associate Professor, Department of Medical Oncology, SKIMS, Srinagar, India \\ ${ }^{8}$ Director and Professor, Head, Molecular Oncology Lab, Department of Biochemistry, Maulana Azad Medical College and Associated hospitals, New Delhi, India
}

\section{Abstract}

Background: Apoptotic inhibitor gene survivin regulates apoptosis and cell cycle progression. Functional polymorphism in the promoter region of survivin influences its expression may lead to the development of several cancers including lung cancer. Our study aimed to investigate the association of survivin-31G $>\mathrm{C}$ polymorphism with the risk of NSCLC in Indian population.

Methods: A hospit al-based case control study of 136 cases and 136 age-gender matched healthy controls was performed by PCR-RFLP.

Results: Our findings reveal that a statistically increased risk and poor survival was associated with the BIRC5 -31CC genotype (OR $3.13,95 \% \mathrm{Cl} 1.57-6.25)$ compared to the genotype containing G allele GC (OR 1.22, 95\% $\mathrm{Cl}$ 0.69-2.14). In addition significant association was found with stage and distant metastasis status of NSCLC patients.

Conclusions: Our results conclude that the function polymorphism $(-31 \mathrm{G}>\mathrm{C})$ in the promoter of survivin gene is associated with risk and susceptibility to NSCLC.

Abbreviations: NSCLC: Non Small Cell Lung Cancer; SCC: Squamous Cell Carcinoma; ADC: Adenocarcinoma; CDE/CHR: Cell Cycle Dependent Elements / Cell Cycle Homology Regions

\section{Introduction}

Lung cancer, which involves malignant proliferation of the epithelial lining of the lower respiratory tract, is one of the most common forms of malignancy leading to the major cause of cancer related deaths around the world [1] including India. Lung cancer constituted $14.4 \%$ of all cancers in a review of 9210 consecutive autopsies by Banker [2]. Cigarette smoking constitutes $80 \%$ of the attributable risk of lung cancer, but only a small proportion of smokers will develop lung cancer, suggesting that there is an inter individual variation in genetic susceptibility to lung cancer in the general population [1]. Apoptosis plays an important role in the development and in tissue homeostasis $[3,4]$. Defects in the regulation of apoptosis may cause accumulation of virtually immortal cells and can lead to many human disorders including cancer [5]. Survivin gene, member of IAP family, located at chromosome $17 \mathrm{q} 25$ encoding $16.5 \mathrm{KDa}$ protein involved in cell cycle regulation. Survivin is ubiquitous in embroyonic or fetal or cancerous tissues, while undetected in most terminally differentiated normal adult tissues [6]. Survivin plays a critical role in carcinogenesis, with important biological, prognostic and therapeutic implications.

In order to understand the biology of cancer development and prognosis, the information from SNPs in various genes at molecular level is believed to help new effective treatment modalities and predict the prognosis. Polymorphism located in $\mathrm{CDE} / \mathrm{CHR}$ region of survivin $(-31 G>C)$ is associated with the alteration of the survivin gene expression [5,7]. Several population based studies indicated survivin polymorphism were associated with human cancers [8-10]. However till date there are only few studies on relationship between survivin gene polymorphism and risk of NSCLC. No similar study has been conducted yet in Indian population based on the key role of survivin in carcinogenesis and association of survivin gene polymorphism $(-31 \mathrm{G} / \mathrm{C})$ with its expression and other cancers. We hypothesized that polymorphism in BIRC5 gene might modulate risk and susceptibility to NSCLC.

\section{Materials and Methods}

\section{Study population and sample collection}

All subjects were biologically unrelated ethnic Indians. Patients were selected from an ongoing molecular study of NSCLC conducted in the Department of Biochemistry Maulana Azad Medical College New Delhi. The study includes 136 NSCLC patients and 136 healthy

*Corresponding author: Dr. Alpana Saxena, Director, Professor and Head Molecular Oncology Lab, Department of Biochemistry, Maulana Azad Medica College and Associated Hospitals, New Delhi, India, Tel: +91-9868937401; E-mail: drrashidmamc@gmail.com

Received July 25, 2012; Accepted August 17, 2012; Published August 20, 2012

Citation: Javid J, Mir R, Ahamad I, Farooq S, Yadav P, et al. (2012) Clinical and Prognostic Significance of Promoter Polymorphism (-31GC) of Anti Apoptotic Gene Survivin (BIRC5) in North India Patients with Non Small Cell Lung Cancer. J Cancer Sci Ther 4: 276-280. doi:10.4172/1948-5956.1000155

Copyright: (C) 2012 Javid J, et al. This is an open-access article distributed unde the terms of the Creative Commons Attribution License, which permits unrestricted use, distribution, and reproduction in any medium, provided the original author and source are credited. 
Citation: Javid J, Mir R, Ahamad I, Farooq S, Yadav P, et al. (2012) Clinical and Prognostic Significance of Promoter Polymorphism (-31GC) of Anti Apoptotic Gene Survivin (BIRC5) in North India Patients with Non Small Cell Lung Cancer. J Cancer Sci Ther 4: 276-280. doi:10.4172/19485956.1000155

controls frequency matched to the cases in age ( \pm 5 years), sex and ethnicity. Patients with a history of previous cancer or metastasized cancer from other organs except lung were excluded. All controls, like the cases, were the residents of North India. The study was approved by the institutional ethics committee, Maulana Azad Medical College New Delhi.

\section{Genotype analysis}

Genomic DNA was extracted from blood samples in EDTA using DNA sure blood mini kit (Nucleo-pore Genetix brand) according to the manufacturer's instructions. Survivin -31G/C genotype (rs 9904341) was analysed using PCR RFLP [11]. Genotyping was performed without the knowledge of the case/control status of the study subjects. The primers used for PCR -RFLP were Forward 5'-CGTTCTTTGAAAGCAGTCGAG-3' and Reverse 5'-TGTAGAGATGCGGTGGTCCT-3'. resulting in a PCR product of 329bp (Figure 1a). Restriction digestion with EcoO109I (Fermantas) resulted in CC-329bp, GG- 234bp+92bp and CG - 329bp+234bp+92bp product, visualized on $2 \%$ agarose gel containing ethidium bromide. (Figure 1b) The amplification was accomplished with a $25 \mu \mathrm{l}$ reaction mixture containing $5 \mu \mathrm{l}$ of $20 \mathrm{ng}$ template DNA, $0.25 \mu \mathrm{l} 25$ pmol each primers, $2.5 \mu \mathrm{l} 10 \mathrm{mM}$ dNTPs, $1.5 \mu \mathrm{l}$ of $20 \mathrm{mM} \mathrm{MgCl}_{2}, 0.3 \mu \mathrm{l}$ of $5 \mathrm{U} /$ $\mu \mathrm{l}$ Taq polymerase with $2.5 \mu \mathrm{l}$ of $10 \mathrm{X}$ Taq Buffer (Fermantas). The amplification conditions were $10 \mathrm{~min}$ of initial denaturation at 95C; 40 cycles at $95 \mathrm{C}$ for $45 \mathrm{~s}, 66.7 \mathrm{C}$ for $45 \mathrm{~s}$ and $72 \mathrm{C}$ for $45 \mathrm{~s}$ with a final $10 \mathrm{~min}$ extension step at $72 \mathrm{C}$.

\section{Statistical analysis}

Differences in selected demographic variables and survivin -31G/C genotype frequencies between the cases and controls were evaluated by using the Chi-square test. The associations between $-31 \mathrm{G} / \mathrm{C}$ variant genotypes and risk of NSCLC cancer were estimated by computing the odds ratios (ORs) and their 95\% confidence intervals (CIs) from both univariate and multivariate logistic regression analysis. Fisher Exact Test was performed for the values below 5. Survival analysis was performed by using Kaplan-Meier survival curve. Statistical difference was considered significant for $\mathrm{P}$ values $<0.05$.

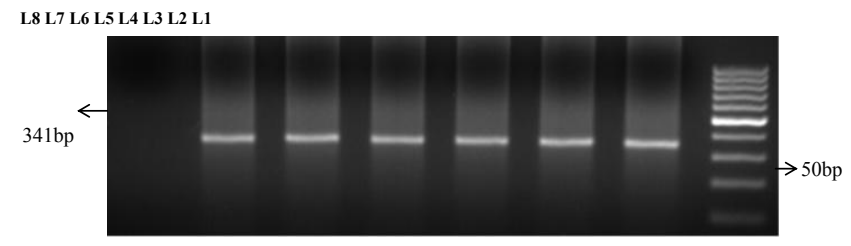

Figure 1a: PCR amplification of Survivin $-31 \mathrm{G} / \mathrm{C}$ showing amplified size of $341 \mathrm{bp}$ (L2-L7) ; L1 :100bp molecular weight marker and L8 -Negative control.

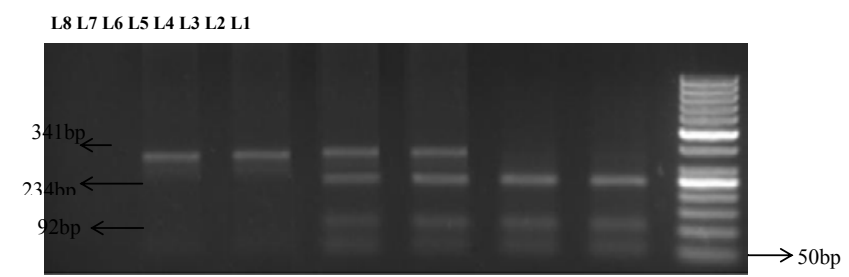

Figure 1b: EcoO109l Restriction digested PCR product of Survivin-31G/C L1 -100bp molecular weight marker; L2, L3- homozygous GG genotype L4,L5- heterozygous GC genotype L6, L7-Homogygous CC genotype and L8 -Negative control.

\begin{tabular}{|c|c|c|}
\hline Variable & NSCLC patients(\%) & Healthy Controls(\%) \\
\hline Total no. & 136 & 136 \\
\hline \multicolumn{3}{|l|}{ Sex } \\
\hline Males & $110(80.9)$ & 110(80.9) \\
\hline Females & 26(19.1) & 26(19.1) \\
\hline \multicolumn{3}{|l|}{ Age(Years) } \\
\hline$\leq 45$ & $24(17.6)$ & $24(17.6)$ \\
\hline$>45$ & $112(82.3)$ & 112(82.3) \\
\hline \multicolumn{3}{|l|}{ Smoking status } \\
\hline Non Smoker & $33(24.3)$ & $33(24.3)$ \\
\hline Smokers & 103(75.7) & 103(75.7) \\
\hline \multicolumn{3}{|l|}{ Smoking level(pack year) } \\
\hline $\operatorname{Mild}(\leq 10)$ & $9(8.9)$ & \\
\hline Moderate $(\leq 40)$ & $49(48.5)$ & \\
\hline Heavy $(>40)$ & $43(42.6)$ & \\
\hline \multicolumn{3}{|l|}{ Histological type } \\
\hline SCC & $79(58.1)$ & \\
\hline ADC & $57(41.9)$ & \\
\hline \multicolumn{3}{|l|}{ TNM stage } \\
\hline Early(I \& II) & $51(37.5)$ & \\
\hline Advanced(III \& IV) & $85(62.5)$ & \\
\hline \multicolumn{3}{|l|}{ Distant metastasis } \\
\hline Positive & $35(25.7)$ & \\
\hline Negative & 101(74.3) & \\
\hline \multicolumn{3}{|c|}{ Family history of any cancer } \\
\hline Significant & $18(13.2)$ & \\
\hline Non significant & $118(86.8)$ & \\
\hline \multicolumn{3}{|l|}{ Cytological type } \\
\hline \multicolumn{3}{|l|}{ Squamous cell carcinoma } \\
\hline Well differentiated & $43(54.4)$ & \\
\hline Moderately differentiated & $22(27.8)$ & \\
\hline Poorly differentiated & 14(17.7) & \\
\hline \multicolumn{3}{|l|}{ Adenocarcinoma } \\
\hline Well differentiated & $11(19.3)$ & \\
\hline Moderately differentiated & $16(28.1)$ & \\
\hline Poorly differentiated & $30(52.6)$ & \\
\hline \multicolumn{3}{|l|}{ Malignant pleural effusion } \\
\hline Yes & $54(39.7)$ & \\
\hline No & $82(60.3)$ & \\
\hline
\end{tabular}

Table 1: Demographic characteristics of NSCLC patients and cancer free healthy controls.

\section{Results}

\section{General characteristics of study population}

The demographic variables among cases and healthy controls are summarized in Table 1 . Briefly among NSCLC cases 110 were male and only 26 were females. Smokers constitute more than 75 percent with $27.2 \%$ as current and 72.8 as ex-smokers, which had 
Citation: Javid J, Mir R, Ahamad I, Farooq S, Yadav P, et al. (2012) Clinical and Prognostic Significance of Promoter Polymorphism (-31GC) of Ant Apoptotic Gene Survivin (BIRC5) in North India Patients with Non Small Cell Lung Cancer. J Cancer Sci Ther 4: 276-280. doi:10.4172/19485956.1000155

left smoking from more than 6 months. Only few patients were with some significant family history of lung cancer or any other cancer. Histological studies revealed 79 cases with Squamous cell carcinoma, 57 with adenocarcinoma. Two age groups were made, patients with age $\leq 45$ which include 24 cases and $\geq 45$ which include 112 cases. 51 and 57 cases were in early stage and advanced stages respectively.

\section{Allele and genotype distribution}

The genotyping results are shown in Table $2 \mathrm{a}$ and $2 \mathrm{~b}$. The frequencies of survivin (-31G/C) GG, CG and CC genotypes among patients were significantly different compared to controls (Chi square - 7.9, df $2 \& \mathrm{p}=0.0193$ ), with the CC homozygotes being significantly overrepresented among patients compared to controls (32.3\% vs.17.6\%) The frequency of the genotypes GG, CG and CC among healthy controls was $34.6 \%, 50.7 \%$ and $14.7 \%$ and of the NSCLC patients were $24.2 \%$, $43.4 \%$ and $32.3 \%$ respectively. The frequencies of BIRC5 -31G/C genotypes with respect to NSCLC stage and distant metastasis status among patients were statistically significant $\mathrm{p}=<0.0001$ and $\mathrm{p}=<0.0001$ whereas there was not any significant difference with respect to other parameter's like gender, smoking status, significant family history of any cancer and smoking level.

\section{Association of NSCLC risk and survivin -31G/C polymorphism}

An unconditional logistic regression was used to estimate associations between the genotypes and risk of NSCLC. It was found that an increased risk of NSCLC was associated with the -31CC allele in an allele dosage-dependent manner. Compared to the GG genotype, the ORs for the GC and CC genotype were 1.22 (95\% CI 0.69-2.14), and 3.13 (95\% CI 1.57-6.25) respectively, suggesting a possible dominant effect of this polymorphism (Table 3 ).

\section{Survivin genotypes and survival analysis}

Follow-up of patients regarding survival was performed with median duration of 11.25 months (range, $0.5-127.5$ months). A total of 84 patients suffered cancer related deaths during the follow up period. It was observed that the survivin -31CC (Figure 2a) and GC + CC (Figure $2 \mathrm{~b}$ ) genotype was significantly associated with poor survival $\mathrm{p}=0.0006$ and $\mathrm{p}=0.0005$ respectively. Patient's survival was calculated using log-rank (Mantel - Cox) test. The estimated median survival time for patients with survivin -31GG, GC, GC + CC and CC genotype were $30,14.5,12.0$ and 10.5 months respectively.

\section{Discussion}

In the present study, we examined whether promoter polymorphism in survivin gene $(-31 \mathrm{G} / \mathrm{C})$ is associated with the risk of developing NSCLC. Our results obtained by analyzing 272 subjects demonstrate that the functional polymorphisms located in $\mathrm{CDE} / \mathrm{CHR}$ region of survivin $(-31 \mathrm{G}>\mathrm{C})$ have a significant impact on the risk of developing NSCLC. The CC genotype was associated with the approximately 1.9 fold increased risk of NSCLC and was more pronounced in subjects who were in advanced stage with positive distant metastasis status

\begin{tabular}{|l|l|l|l|l|l|}
\hline Variable & Cases & Controls & Chi-square & df & P -value \\
\hline GG & $33(24.2)$ & $47(34.6)$ & 12.2 & 2 & 0.022 \\
\hline CC & $44(32.3)$ & $20(14.7)$ & & & \\
\hline GC & $59(43.4)$ & $69(50.7)$ & & & \\
\hline
\end{tabular}

Table 2a: Overall frequency of survivin(- $31 \mathrm{G} / \mathrm{C})$ polymorphism in cases and controls.

\begin{tabular}{|c|c|c|c|c|c|c|}
\hline Variables & GG & CC & GC & \begin{tabular}{|l|} 
Chi- \\
square
\end{tabular} & df & $\begin{array}{l}\mathrm{P}- \\
\text { value }\end{array}$ \\
\hline Males & $28(25.45)$ & $38(34.5)$ & $44(40.0)$ & 2.71 & 2 & 0.257 \\
\hline Females & $5(19.23)$ & $6(23.07)$ & $15(57.69)$ & & & \\
\hline \multicolumn{7}{|l|}{ Age group } \\
\hline$\leq 45$ & $4(16.7)$ & $7(29.16)$ & $13(54.17)$ & 1.57 & 2 & 0.456 \\
\hline$>45$ & $29(25.9)$ & $37(33.0)$ & $46(41.1)$ & & & \\
\hline \multicolumn{7}{|l|}{ Stage } \\
\hline Early stage(I \& II) & $21(41.2)$ & $2(3.9)$ & $25(49.0)$ & 31.12 & 2 & $<0.0001$ \\
\hline $\begin{array}{l}\text { Advanced stage(III } \\
\& \text { IV) }\end{array}$ & $12(14.1)$ & $42(49.9)$ & $34(40.0)$ & & & \\
\hline \multicolumn{7}{|l|}{ Smoking status } \\
\hline Non smoker & $11(31.4)$ & $9(25.7)$ & $15(42.8)$ & 1.64 & 2 & 0.440 \\
\hline Smoker & $22(21.7)$ & $35(34.7)$ & $44(43.6)$ & & & \\
\hline \multicolumn{7}{|c|}{ Smoking level(pack year) } \\
\hline $\operatorname{Mild}(\leq 10)$ & $0(0)$ & $5(55.6)$ & $4(44.4)$ & 5.14 & 4 & 0.27 \\
\hline Moderate $(\leq 40$ & $13(26.5)$ & $13(26.5)$ & $23(46.9)$ & & & \\
\hline Heavy $(>40)$ & $9(21.0)$ & $17(39.5)$ & $17(39.5)$ & & & \\
\hline \multicolumn{7}{|l|}{ Smoking type } \\
\hline Cigarette & $4(14.2)$ & $13(46.5)$ & 11(39.3) & 21.96 & 8 & 0.005 \\
\hline Bidi & $0(0)$ & $3(27.3)$ & $8(42.3)$ & & & \\
\hline Hookah & $10(38.5)$ & $5(19.2)$ & $11(42.3)$ & & & \\
\hline Cigarette + Bidi & $1(8.3)$ & $9(75.0)$ & $2(16.6)$ & & & \\
\hline Cigarette + Hookah & $8(34.8)$ & $6(26.0)$ & $9(39.2)$ & & & \\
\hline \multicolumn{7}{|l|}{ Histological type } \\
\hline $\operatorname{SCC}$ & $21(26.6)$ & $27(34.2)$ & $31(39.3)$ & 1.36 & 2 & 0.506 \\
\hline$A D C$ & $12(21.1)$ & $17(29.8)$ & $28(49.1)$ & & & \\
\hline \multicolumn{7}{|l|}{ Metastasis } \\
\hline Positive & $6(17.1)$ & $22(62.9)$ & $7(20.0)$ & 20.48 & 2 & $<0.0001$ \\
\hline Negative & $27(26.7)$ & 22(21.9) & $52(51.5)$ & & & \\
\hline \multicolumn{7}{|c|}{ Family history of any cancer } \\
\hline Significant & $6(33.3)$ & $5(27.8)$ & $7(38.9)$ & 0.93 & 2 & 0.628 \\
\hline Non Significant & $27(22.9)$ & $39(33.1)$ & $52(44.0)$ & & & \\
\hline \multicolumn{7}{|l|}{ SCC Cytology } \\
\hline Well differentiated & $10(23.8)$ & $16(38.1)$ & $16(38.1)$ & & & 0.75 \\
\hline $\begin{array}{l}\text { Moderately } \\
\text { differentiated }\end{array}$ & $8(36.4)$ & $7(31.8)$ & $7(31.8)$ & & & \\
\hline Poorly differentiated & $4(28.6)$ & $3(21.4)$ & $6(42.8)$ & & & \\
\hline \multicolumn{7}{|l|}{ ADC Cytology } \\
\hline Well differentiated & $4(36.4)$ & $1(9.0)$ & $6(54.5)$ & & & 0.37 \\
\hline $\begin{array}{l}\text { Moderately } \\
\text { differentiated }\end{array}$ & $2(12.5)$ & $5(31.2)$ & $9(56.2)$ & & & \\
\hline Poorly differentiated & $5(16.7)$ & 11(36.7) & $14(46.7)$ & & & \\
\hline
\end{tabular}

Table 2b: Frequency of survivin(-31 G/C) polymorphism in cases with respect to different parameters.

at diagnosis. The frequency of CC allele was more among patients with squamous-cell carcinoma than adenocarcinoma of NSCLC and smokers. Individuals with at least one $-31 \mathrm{G}$ allele were at decreased risk of over all NSCLC as compared to those with -31CC genotype. In vitro studies reveals that the transcriptional activity of $-31 \mathrm{G}$ allele is significantly lower than $-31 \mathrm{C}$ allele. As this polymorphism is located in the binding site for $\mathrm{CDE} / \mathrm{CHR}$ repressor in the survivin promoter thus influence the survivin gene expression [9]. Studies on NSCLC cell line A549 revealed that over expression of survivin leads to decreased apoptosis [12] and presence of the $-31 \mathrm{G} / \mathrm{C}$ polymorphism was more frequent in cancer cells with $-31 \mathrm{C}$ allele resulting in increased survivin expression both at mRNA and protein level [13] thus may accelerate 
Citation: Javid J, Mir R, Ahamad I, Farooq S, Yadav P, et al. (2012) Clinical and Prognostic Significance of Promoter Polymorphism (-31GC) of Anti Apoptotic Gene Survivin (BIRC5) in North India Patients with Non Small Cell Lung Cancer. J Cancer Sci Ther 4: 276-280. doi:10.4172/19485956.1000155

tumor cell proliferation and may ultimately lead to more aggressive carcinomas in lung.

Decreased risk was observed with GG as compared to CC variant of survivin $-31 \mathrm{G} / \mathrm{C}$ in lung cancer [9]. A significant increased risk associated with variant -31CC genotype was observed in other tumors like bladder cancer [14,15], colorectal cancer [16]. Esophageal cancer [17], urothelial carcinoma [18] and gastric cancer [10] etc.., (Table 4).

Present study reveals that the frequency of -31CC genotype was found to be significantly higher in case of advanced stage with distant metastasis $(\mathrm{p}<0.0001)$. Histologically well differentiated SCC and poorly differentiated ADC patients showed higher percentage of -31CC genotype [19]. Higher frequency of CC genotype was found in patients who smoke cigarette as well as bidi as their smoking habit thus predicting cigarette and bidi as risk factor of non small cell lung cancer in Indian population.

In addition survivin polymorphism were significantly associated with the poor survival outcome of patients with -31CC genotype and the median survival times was found to be of just 10.5 months. In other tumors like colorectal cancer -31CC was found to be significantly associated with poor survival [16-23]. To the best of our knowledge, this is the first case-control study to investigate the polymorphisms in cell cycle regulatory genes survivin $(-31 \mathrm{G} / \mathrm{C})$ are associated with NSCLC risk among Indian patients.

\section{Conclusion}

It is suggested that the survivin polymorphisms may be a genetic

\begin{tabular}{|l|l|l|l|}
\hline Variable & Cases & Controls & OR(95\%Cl) \\
\hline GG & 33 & 47 & 1 \\
\hline CC & 44 & 20 & $3.13(1.57-6.25)$ \\
\hline GC & 59 & 69 & $1.22(0.69-2.14)$ \\
\hline CC+GC & 103 & 89 & $1.64(0.97-2.79)$ \\
\hline
\end{tabular}

Table 3: Risk of NSCLC associated with the survivin(-31G/C) genotypes.

\begin{tabular}{|c|c|c|c|c|c|c|}
\hline \multirow[t]{2}{*}{$\begin{array}{l}\text { S. } \\
\text { No }\end{array}$} & \multirow[t]{2}{*}{ Region } & \multirow[t]{2}{*}{ Cancer Type } & \multicolumn{4}{|c|}{ CASES } \\
\hline & & & n & CC & CG & GG \\
\hline 1 & Korea [9] & Lung cancer & 582 & 184(31.6) & $259(44.5)$ & 139(123.9) \\
\hline 2 & China [20] & NSCLC & 567 & $129(22.8)$ & $314(55.4)$ & $124(21.8)$ \\
\hline 3 & Brazil [21] & Gastric cancer & 47 & $8(14.0)$ & $28(49.1)$ & $21(36.9)$ \\
\hline 4 & China [22] & $\begin{array}{l}\text { Nasopharyngeal } \\
\text { cancer }\end{array}$ & 855 & 236(28.0) & $403(47.7)$ & $205(24.3)$ \\
\hline 5 & Hungary [5] & Cervical cancer & 81 & $7(8.6)$ & $45(55.6)$ & $29(35.8)$ \\
\hline 6 & China [23] & Gastric cancer & 220 & $64(29.0)$ & $110(50.0)$ & $46(21.0)$ \\
\hline 8 & Taiwan [18] & Urothelial cancer & 190 & $66(34.7)$ & $91(47.9)$ & $33(17.4)$ \\
\hline 9 & Greece [16] & Colorectal cancer & 312 & $113(36.2)$ & $131(42.0)$ & $68(21.8)$ \\
\hline 10 & USA [11] & Ovarian cancer & 168 & $28(16.8)$ & $78(46.7)$ & $61(36.5)$ \\
\hline 11 & China [23] & $\begin{array}{l}\text { Hepatocellular } \\
\text { cancer }\end{array}$ & 178 & $35(19.7)$ & $100(56.2)$ & $43(24.1)$ \\
\hline
\end{tabular}

Table 4: Frequency of Survivin -31GC polymorphism in lung and other cancers : Worldwide scenario.

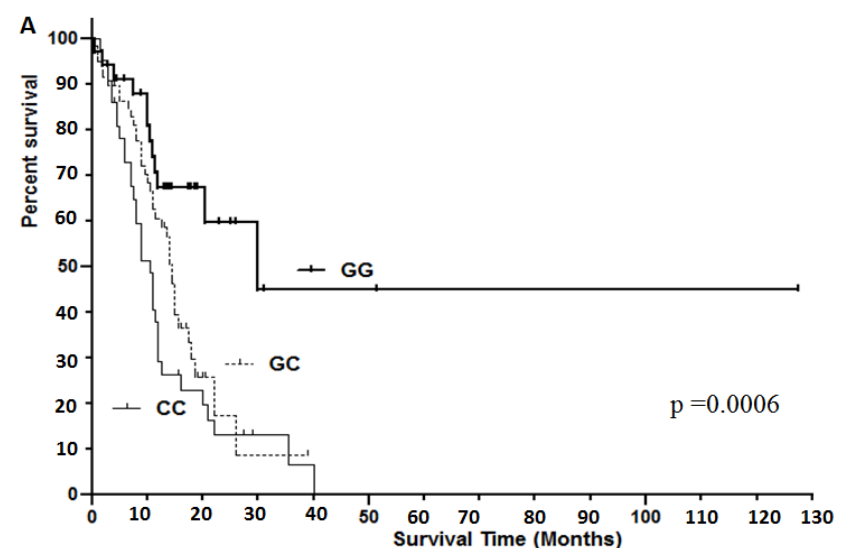

B

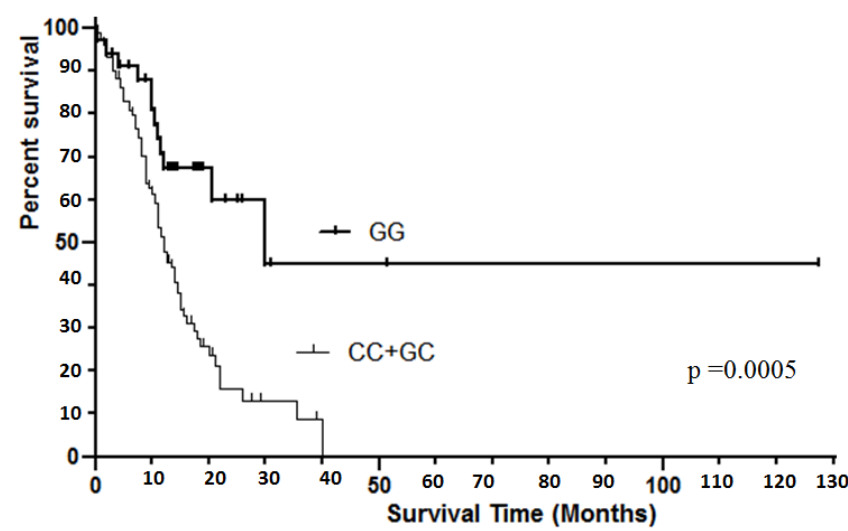

Figure 2: Kaplan -Meier survival curves for NSCLC patients with respect to Survivin $(-31 \mathrm{G} / \mathrm{C})$ polymorphism.

modifier for NSCLC risk and prognosis in Indian population with NSCLC. Also -31CC genotypes were associated with an increased risk than -31GG genotype besides -31G/C genotypes might be a useful genetic marker in peripheral blood to determine susceptibility to advanced stage with distant metastasis status of NSCLC. However, independent large population-based prospective studies for more rigorous analyses of subgroups are needed to validate our findings.

\section{Acknowledgment}

We are thankful to Regional Cancer Center, SKIMS, Srinagar and All India Institute of Medical Sciences, New Delhi, for assistance in recruiting the subjects and Department of Non Communicable Disease, Indian Council of Medical Research for the grant support.

\section{References}

1. Spitz MR, Wei Q, Dong Q, Amos Cl, Wu X (2003) Genetic susceptibility to lung cancer: the role of DNA damage and repair. Cancer Epidemiol Biomarkers Prev 12: 689-698.

2. Nagrath SP, Hazra DK, Lahiri B, Kishore B, Kumar R (1970) Primary carcinoma of lung: clinico-pathological study of 35 cases. Indian J Chest Dis 12: 15-24.

3. Thompson CB (1995) Apoptosis in the pathogenesis and treatment of disease. Science 267: 1456-1462.

4. Raff M (1998) Cell suicide for beginners. Nature 396: 119-122.

5. Borbély AA, Murvai M, Szarka K, Kónya J, Gergely L, et al. (2007) Survivin promoter polymorphism and cervical carcinogenesis. J Clin Pathol 60: 303-306.

6. Hajra KM, Liu JR (2004) Apoptosome dysfunction in human cancer. Apoptosis 9: 691-704.

7. Mityaev MV, Kopantzev EP, Buzdin AA, Vinogradova TV, Sverdlov ED (2008) 
Citation: Javid J, Mir R, Ahamad I, Farooq S, Yadav P, et al. (2012) Clinical and Prognostic Significance of Promoter Polymorphism (-31GC) of Anti Apoptotic Gene Survivin (BIRC5) in North India Patients with Non Small Cell Lung Cancer. J Cancer Sci Ther 4: 276-280. doi:10.4172/19485956.1000155

Functional significance of a putative sp1 transcription factor binding site in the survivin gene promoter. Biochemistry (Mosc) 73: 1183-1191.

8. Yang X, Xiong G, Chen X, Xu X, Wang K, et al. (2009) Polymorphisms of survivin promoter are associated with risk of esophageal squamous cell carcinoma. J Cancer Res Clin Oncol 135: 1341-1349.

9. Jang JS, Kim KM, Kang KH, Choi JE, Lee WK, et al. (2008) Polymorphisms in the survivin gene and the risk of lung cancer. Lung Cancer 60: 31-39.

10. Cheng ZJ, Hu LH, Huang SJ (2008) Correlation of -31G/C polymorphisms of survivin promoter to tumorigenesis of gastric carcinoma. Ai Zheng 27: 258-263.

11. Han CH, Wei Q, Lu KK, Liu Z, Mills GB, et al. (2009) Polymorphisms in the survivin promoter are associated with age of onset of ovarian cancer. Int J Clin Exp Med 2: 289-299.

12. Karna P, Sharp SM, Yates C, Prakash S, Aneja R (2009) EEM011 activates a survivin-dependent apoptotic program in human non-small cell lung cancer cells. Mol Cancer 8: 93

13. Xu Y, Fang F, Ludewig G, Jones G, Jones D (2004) A mutation found in the promoter region of the human survivin gene is correlated to overexpression of survivin in cancer cells. DNA Cell Biol 23: 527-537.

14. Jaiswal PK, Goel A, Mandhani A, Mittal RD (2012) Functional polymorphisms in promoter survivin gene and its association with susceptibility to bladder cancer in North Indian cohort. Mol Biol Rep 39: 5615-5621.

15. Kawata N, Tsuchiya N, Horikawa Y, Inoue T, Tsuruta H, et al. (2011) Two survivin polymorphisms are cooperatively associated with bladder cancer susceptibility. Int J Cancer 129: 1872-1880.
16. Gazouli M, Tzanakis N, Rallis G, Theodoropoulos G, Papaconstantinou I, et al. (2009) Survivin $-31 \mathrm{G} / \mathrm{C}$ promoter polymorphism and sporadic colorecta cancer. Int J Colorectal Dis 24: 145-150.

17. Yang X, Xiong G, Chen X, Xu X, Wang K, et al. (2009) Polymorphisms of survivin promoter are associated with risk of esophageal squamous cell carcinoma. J Cancer Res Clin Oncol 135: 1341-1349.

18. Wang YH, Chiou HY, Lin CT, Hsieh HY, Wu CC, et al. (2009) Association between survivin gene promoter $-31 \mathrm{C} / \mathrm{G}$ polymorphism and urothelial carcinoma risk in Taiwanese population. Urology 73: 670-674.

19. Suga JM, Nguyen DV, Mohammed SM, Brown M, Calhoun R, et al. (2010) Racial disparities on the use of invasive and noninvasive staging in patients with non-small cell lung cancer. J Thorac Oncol 5: 1772-1778.

20. Borges Bdo N, Burbano RR, Harada ML (2011) Survivin -31C/G polymorphism and gastric cancer risk in a Brazilian population. Clin Exp Med 11: 189-193.

21. Ma F, Zhang H, Zhai Y, Huang W, Zhao C, et al. (2011) Functional polymorphism $-31 \mathrm{C} / \mathrm{G}$ in the promoter of BIRC5 gene and risk of nasopharyngeal carcinoma among chinese. PLoS One 6: e16748.

22. Yang L, Zhu H, Zhou B, Gu H, Yan H, et al. (2009) The association between the survivin $\mathrm{C}-31 \mathrm{G}$ polymorphism and gastric cancer risk in a Chinese population Dig Dis Sci 54: 1021-1028.

23. Li Y, Wang J, Jiang F, Lin W, Meng W (2012) Association of polymorphisms in survivin gene with the risk of hepatocellular carcinoma in Chinese han population: a case control study. BMC Med Genet 13: 1. 